\title{
Micronutrient Composition of Selected Indigenous foodcrops in Okigwe Local Government Area, Imo State
}

\author{
Ubosi, N. I. \\ Public Health Department, Faculty of Health Sciences, National Open University of Nigeria, Lagos
}

\begin{abstract}
This study assessed micronutrient profile of selected indigenous foodcrops. The selected foodcrops includes Nchuanwu(Ocimumgratissimum), Ukazi (Gnetumafricanum), Utazi (Gongronemalatifolium), Uziza (Piper guineense), Ofe (Solanummacrocapon), Okwurubekee(Carica papaya), Ukpa (Tetracapidiumconophorum), Onugbu (Vernoniaamygdalina), and Ugu (Telferiaoccidentalis) which were purchased from a local market in OkigweLocal Government Area of Imo state. The proximate and micronutrient composition of the foodcrops were determined by official method of AOAC; while means and standard deviation were used to analyze the data variables. These indigenous foodcrops were found to be good and cheap sources of micronutrient (zinc, iron, calcium, and vitamin A) and protein. However, they contain some anti-nutrients such as phytate and tannins which are within normal range. The result confirms that our indigenous fruit, seeds and vegetables are good sources of important minerals and vitamins. There is need for massive enlightenment of the populace and policy makers for increase in production, better processing, preservation and consumption of these indigenous foodcrops.
\end{abstract}

Key words:Foodcrops, seeds, micronutrient, vegetables, indigenous.

\section{Introduction}

Those nutrients required in small or minute quantities are called micronutrients while those required in large amounts are called or referred to as macro nutrients. Micronutrients are a combination of vitamins and minerals, which are all found in our indigenous foodcrops.Foods from natural environments which have been incorporated into a group of indigenous people's cultural food use patterns are referred to as indigenousfood[1]. Sustainable use of indigenous food crops will help in addressing the problems of food security both in quality and quantity at local and national levels [2]. Moving to a healthier vegetable-rich diet is necessary, especially now that the world is experiencing an undesirable impact of intensive livestock production system on planet's resources and ecosystems[3].

With a great increase in global malnutrition, reports have it that about 2-3 billion people are malnourished [4], micro nutrient deficiency has niches within the ecological confines of the hydra headed malnutrition [5]. Apart from the hidden hunger, diseases are transiting from, the usual protein energy malnutrition, stunting and wasting in most developing countries to the more complex non communicable diseases such as cardiovascular heart disease, cancer and obesity [6]. This trend in nutrition transition is gaining an upper hand as people; even those in the rural areas are neglecting indigenous food crops which are cheaper and healthier, for the more refined high salt, high sugar processed foods with low fibre. According to [7], traditional food system plays significant roles in meeting the nutritional status, health and wellbeing of indigenous people. Among the important contributors to Africa's high burden of malnutrition is poor nutrient intake resulting from nutritionally inadequate diets and poor feeding practices. Dietary diversity, which entails the intake of variety of foods across and within food groups and species, is shown to be crucial for adequate nutrient intake and optimal nutritional status, especially in developing countries [2].

Furthermore, food production systems in the majority of African countries have focused mainly on few species of crops, (mainly cereal grains and cash crops) with little or no attention to production of nutritious nonfood grain commodities such as pulses, vegetables, fruits, and oilseeds, from indigenous species of crop, [2].Probablythis may be due to their inadequate knowledge of the nutrient composition of these indigenous food cropsand its contribution to dietary intake. These indigenous food crops contain both macro and micro nutrients that are essential for proper growth and functioning of the human body. Nigeria is a multicultural society with different indigenous food crops, indigenous to the different ethnic and cultural societies such as the Igbos.

This study therefore aimed at determining the proximate and micronutrient composition of some selected indigenous foodcrops. These include:Nchuanwu (Ocimumgratissimum), Ukazi (Gnetumafricanum), Utazi (Gongronemalatifolium), Uziza (Piper guineense), Ofe(Solanummacrocapon), Okwurubekee (Caricapapaya), Ukpa (Tetracapidiumconophorum), Onugbu (Vernoniaamygdalina), Ugu (Telferiaoccidentalis) 
The objectives of the study include:

\section{Objectives of the Research}

i. to ascertain the proximate composition of selected indigenous foodcrops in Okigwe

ii. to estimate the zinc, iron, vitamin A,calcium and fibre contents of the selected indigenous foodcrops

iii. to identify the phytate and tannin levels of selected indigenous foodcrops

iv. to make appropriate recommendations based on the findings.

\section{Research Questions}

RQ1: What is the proximate composition of the selected indigenous foodcrops?

RQ2: What are the zinc, iron, vitamin A, calcium and fibre contents of the selected indigenous foodcrops?

PQ3: What are the phytate and tannin levels of selected indigenous foodcrops?

\section{Study Location}

\section{Materials and Methods}

The foodcrops studied were purchased from a local market in Okigwe Local Government Area of Imo State. This location waspurposively selected based on the fact that most of the indigenous foodcrops weregrown and consumed in the area. It is bordered by the north by Umuchieze, in the east by Uturu, in the south by Nneato, all in Abia state.

Table 1: Foodcropsused for the study:

Local nameEnglish name Scientific name

NchuanwuScent leave Ocimumgratissimum

UkaziHard leaf Gnetumafricanum

Utazi Bittersweet leaf Gongrenomalatifolium

UzizaPepper leafPiper guineense

EfeGarden egg Solanummacrocapon

OkwurubekeePaw-paw Caricapapaya

UkpaConophorTetracapidiumconophorum

OnugbuBitter leaf Vernoniaamygdalina

UguPumpkin Telferiaoccidentalis

\section{Sample selection/preparation}

Fresh samples of the selected food crops purchased were plucked to obtain the edible portion. Then each of the samples was divided into two.The first sample was for moisture determination and the second half was for proximate and micronutrient analysis.These samples were dried in a drier, milled and parked for final analysis. The analyses were carried out in the Department of Home Science, Nutrition and Dietetics and Crop Science Laboratory at the University of Nigeria,Nsukka.

\subsection{Moisture Determination}

\section{Chemical Analysis}

This was determined by the official method AOAC (2012) using standard hot air oven. About $5 \mathrm{~g}$ of each sample were placed in an air oven $100{ }^{\circ}$ Cuntil constant weight was obtained. Moisture was then calculated using this formula.

\section{1 .2Moisture content determination calculation}

$\%$ moisture $=$ wet weight - dry weight $\times 100$

\section{Wet weight}

\subsubsection{Protein Determination}

Nitrogen was determined by the microkjedahlmethod.The percentage nitrogen was converted to crude protein by multiplying it by a conversion factor of 6.25 .

\subsection{Fat Determination}

Fat content of samples was determined by Soxhletextraction method AOAC (2012). Also 2g of each samplewere extracted using Soxhlet extractor with petroleum ether B.P. $\left(40-60^{\circ} \mathrm{C}\right)$ for $1 \mathrm{hr}$. The solvent free fat was dried in an oven and then cooled in adesiccators andweighed. The content was expressed as the percentage of the raw material. 
Micronutrient Composition of Selected Indigenous food crops in Okigwe Local Government Area,..

\subsection{AshDetermination}

The ash content was determined by the official method of AOAC [8]. Two(2)g of each milled samples were weighed into pre-weighed clean silica dishes. The samples were charred at $500^{\circ} \mathrm{C}$ in a muffle furnace until light grey ash wasobtained. Both the dishes and their contents were removed from the

Crudefurnace and allowed to cool at room temperature in desiccators. Final weights were recorded to obtain ash weight.

\subsection{Fibre Determination}

The crude fibre content of the samples was determined by the official method AOAC [8].

4.6 CarbohydrateDetermination

Carbohydrate content was determined by difference. The determined percentage of crude protein, fat,ash and moisture were summed up and the value subtracted from $100 \%$.

\subsection{Micronutrient Determination}

Minerals such as iron, zinc and calcium were estimated using atomic absorption spectrophotometer. Vitamin A (B- carotene and lycopene )were determined by AOAC (2012) procedure for minerals and vitamins.

\subsection{Phytateand Tannins Analysis of the Samples}

4.8.1Phytate:This was determined by a photometric method adapted from the method of [9]. Five (5) grams of each sample were extracted with $2.4 \% \mathrm{HCL} 0.1 \mathrm{M} \mathrm{NaCl}$ was added to elude inorganic phosphorus and $0.7 \mathrm{MNaCl}$ added to remove phytate. $1 \mathrm{ml}$ of modified wade reagent was added and readings the spectrophotometers were taken at a wavelength of 500nm on a spectrophotometer.

4.8.2Tannin:This was determined by method as determined by [10]. Also, $0.5 \mathrm{~g}$ of each sample was extracted with $3 \mathrm{ml}$ methanol. The filtrate was mixed with $50 \mathrm{ml}$ water. $3 \mathrm{ml}$ of $0.1 \mathrm{M} \mathrm{FeCl}_{2}$ in $\mathrm{NHCl}$ and $0.8 \mathrm{M} \mathrm{K} \mathrm{K}_{2} \mathrm{Fe}(\mathrm{CN})_{6}$ were added to $0.1 \mathrm{ml}$ of the solution. Theextract was read at wavelength of $720 \mathrm{~nm}$ on a spectrophotometer

Data Analysis

Laboratory analyses on samples were done in triplicate. Means and standard deviations of means were calculated for variables.

\section{Results}

Table 2: Proximate Composition of Selected Indigenous Foodcropsper 100g Edible Portion.

\begin{tabular}{|c|c|c|c|c|c|c|c|}
\hline Foodcrops & Moisture & Fat & Protein & Fibre & Ash & CHO & \\
\hline Nchuanwu (Ocimumgratissimum) & & 90.0 & $0.1 \pm 0.1$ & $1.8 \pm 0$. & $.10 .5 \pm 0.1$ & $1 \quad 1.3 \pm 0.1$ & $6.3 \pm 0.1$ \\
\hline Ukazi (Gnetumafricanum) & 63.0 & $0.9 \pm 0.2$ & $3.3 \pm 0.1$ & $4.9 \pm 0.1$ & $5.1 \pm 0.1$ & $22.8 \pm 0.2$ & \\
\hline Utazi (Gongronemalatifolium) & 86.7 & $0.4 \pm 0.4$ & $1.3 \pm 0.0$ & $1.7 \pm 0.1$ & $1.8 \pm 0.1$ & $8.1 \pm 0.1$ & \\
\hline Uziza (Piper guineense) & & 90.0 & $0.2 \pm 0.1$ & $2.7 \pm 0.1$ & $1.9 \pm 0.2$ & $2 \quad 1.7 \pm 0.2$ & $3.5 \pm 0.1$ \\
\hline Garden egg (Solanumspp) & 85.0 & $0.5 \pm 0.1$ & $3.0 \pm 0.1$ & $1.9 \pm 0.3$ & $3 \quad 2.4 \pm 2.8$ & $7.2 \pm 0.1$ & \\
\hline Paw-paw (Carica papaya) & 91.0 & $0.2 \pm 0.1$ & $1.8 \pm 0.2$ & $1.3 \pm 0.1$ & $0.7 \pm 0.1$ & $5.0 \pm 0.7$ & \\
\hline Ukpa (Tetracapidiumconophorum) & 71.0 & $1.5 \pm 0.1$ & $7.0 \pm 0.1$ & $6.8 \pm 0.1$ & $1.7 \pm 0.2$ & $11.8 \pm 0.1$ & \\
\hline Bitter leaf (Vernoniaamygdalina) & & 79.0 & $0.4 \pm 0.2$ & $5.4 \pm 0.1$ & $2.8 \pm 0.1$ & $2.5 \pm 0.1$ & $9.9 \pm 0.1$ \\
\hline Ugu (Telferiaoccidentalis) & 89.0 & $0.2 \pm 0.2$ & $1.0 \pm 0.1$ & $1.7 \pm 0.1$ & $1.7 \pm 0.1$ & $6.4 \pm 0.1$ & \\
\hline
\end{tabular}

Figure 1

\section{Means \pm SD of triplicate determinations}

Table 2 showed the proximate composition of selected indigenous foodcrops. Ukpa had protein content of $7.0 \mathrm{~g}$, paw-paw $1.8 \mathrm{~g}$. Bitter leaf5.4g while ugu had $1.0 \mathrm{~g}$ per $100 \mathrm{~g}$ edible portion respectively. 
Ukpa had a fat content of $1.5 \mathrm{~g}$, paw-paw had $0.2 \mathrm{~g}$, ukazi $0.9 \mathrm{~g}$, uziza $0.2 \mathrm{~g}$, nchuanwu had $0.1 \mathrm{~g}$, utazi $0.4 \mathrm{~g}$, garden egg $0.5 \mathrm{~g}$, ugu had0.2g and that of bitter leaf was $0.4 \mathrm{~g}$ per $100 \mathrm{~g}$ edible portion respectively.

More so, the fibre content of paw-paw was about $1.3 \mathrm{~g}$ per $100 \mathrm{~g}$, garden egg (ofe) $1.9 \mathrm{~g}$, while that of ukpa was about $6.8 \mathrm{~g}$ per $100 \mathrm{~g}$ of edible portion respectively. The selected indigenous vegetables, ukazi had fibre content of $4.9 \mathrm{~g}$, uziza $1.9 \mathrm{~g}$, nchuanwu $0.5 \mathrm{~g}$, utazi $1.7 \mathrm{~g}$, ugu $1.3 \mathrm{~g}$, and bitterleaf $2.8 \mathrm{~g}$, per $100 \mathrm{~g}$, edible portion respectively. Ukazi had ash content of $5.1 \mathrm{~g}$, bitterleaf $2.5 \mathrm{~g}$ and paw-paw $0.7 \mathrm{~g}$ per $100 \mathrm{~g}$ edible portion respectively. Ukazi had carbohydrate content of $22.6 \mathrm{~g}$ per $100 \mathrm{~g}$ while bitterleaf had $9.9 \mathrm{~g}$ and ukpa $11.2 \mathrm{~g}$ per $100 \mathrm{~g}$ edible portion respectively.

Table 3: Micronutrient and anti-nutrient composition of selected indigenous foodcrops per $100 \mathrm{~g}$ edible portion Foodcrops Zinc in Iron in Calcium Retinol Phytate Tannin

RE) mg $\quad \mathrm{mg} \quad$ in $\mathbf{m g} \quad$ in $(\mu \mathrm{g} \quad$ in $\mathbf{m g} \quad$ in $\mathbf{m g}$

\begin{tabular}{|c|c|c|c|c|c|c|c|}
\hline Nchuanwu (Ocimumgratissimum) & & $0.17 \pm 0.1$ & $1.10 \pm 0.1$ & $0.28 \pm 0.1$ & $93.3 \pm 1$ & $19.0 \pm 2$ & $5.49 \pm 0.1$ \\
\hline Ukazi (Gnetumafricanum) & & $0.15 \pm 0.0$ & $4.9 \pm 0.1$ & $0.31 \pm 0.01$ & $41.8 \pm 9$ & $66.0 \pm 3$ & $15.99 \pm 0.1$ \\
\hline Utazi (Gongronemalatifolium) & $0.18 \pm 0.1$ & $0.76 \pm 0.1$ & $1.65 \pm 0.1$ & $45.0 \pm 1 \quad 27$ & $.3 \pm 2$ & $9.33 \pm 0.1$ & \\
\hline Uziza (Piperguineense) & & $0.13 \pm 0.1$ & $0.33 \pm 0.2$ & $0.15 \pm 0.1$ & 43.9 \pm 1 & $19.0 \pm 2$ & $3.32 \pm 1$ \\
\hline Garden egg (Solanumspp) & & $0.10 \pm 0.0$ & $2.00 \pm 0.1$ & $1 \quad 1.6 \pm 0.0$ & $43.6 \pm 1$ & $32.0 \pm 4$ & $5.33 \pm 0.1$ \\
\hline Paw-paw (Carica papaya) & & $0.13 \pm 0.1$ & $0.62 \pm 0.5$ & $0.47 \pm 0.1$ & $15.1 \pm 2$ & $216.5 \pm 1$ & $4.16 \pm 0.1$ \\
\hline Ukpa (Tetracapidiumconophorum) & & $0.10 \pm 0.0$ & $3.75 \pm 0.1$ & $0.24 \pm 0.0$ & $44.8 \pm 1$ & $46.5 \pm 3$ & $7.47 \pm 0.1$ \\
\hline Bitterleaf (Vernoniaamygdalina) & & $0.19 \pm 0.3$ & $0.88 \pm 0.1$ & $1.95 \pm 0.3$ & $66.7 \pm 1$ & $33.4 \pm 2$ & $10.98 \pm 0.0$ \\
\hline Ugu (Telferiaoccidentalis) & $0.10 \pm 0.1$ & $0.48 \pm 0.1$ & $0.26 \pm 0.0$ & $50.9 \pm 1$ & $19.8 \pm 2$ & $3.13 \pm 0.1$ & \\
\hline
\end{tabular}

Means + SD of triplicate determination

$\mathrm{RE}=$ Retinol equivalent

Table 3 showed the micronutrient and anti-nutrient content ofselected indigenousfoodcrops. Utazi had zinc content of $0.2 \mathrm{mg}$ per $100 \mathrm{~g}$, ugu $0.2 \mathrm{mg}$,paw-paw $0.1 \mathrm{mg}$ garden egg (ofe) $0.1 \mathrm{mgand}$ ukpa $0.1 \mathrm{mg}$ per $100 \mathrm{~g}$ edible portion respectively.

However the iron content of ukazi was 4.9 g per $100 \mathrm{~g}$ edible portion, ukpa, $3.6 \mathrm{~g}$, utazi 1.8mg,garden egg (ofe) $2.0 \mathrm{~g}$ and bitter leaf $0.9 \mathrm{mg}$ per $100 \mathrm{~g}$. The iron content of uzizawas about $0.3 \mathrm{mg}$, paw-paw $0.6 \mathrm{gwhile}$ that of ugu was about $0.5 \mathrm{mg} / 100$ gedible portion respectively.

Calcium value of bitterleaf was about $2.0 \mathrm{mg}$ per $100 \mathrm{~g}$, utazi $1.7 \mathrm{mg} / 100 \mathrm{~g}$, garden egg (ofe) $1.6 \mathrm{~g} / 100 \mathrm{~g}$, uziza $0.2 \mathrm{~g} / 100 \mathrm{~g}$ ukazi $0.3 \mathrm{mg} / 100 \mathrm{~g}$ edible portion respectively.

\section{Discussion}

Ukpaan oil seed had the highest protein content $7.0 \mathrm{~g}$ per $100 \mathrm{~g}$ of edible portion. Paw-paw a fruit had protein content of $1.8 \mathrm{~g}$ per $100 \mathrm{~g}$ edible portion. Among the selected indigenous vegetables, bitterleaf had the highest protein content of $5.4 \mathrm{~g}$ whileugu 1.0. also ukpa had fat content of $1.5 \mathrm{~g}$ per $100 \mathrm{~g}$ of edible portion the high fat content could be attributed to the fact that ukpa is an oil seed.

More so, the high fibre content of ukpa, $6.8 \mathrm{~g}$ per $100 \mathrm{~g}$ edible portion was of good quality because studies have shown that fibre reduces blood cholesterol probably by binding bile salts and cholesterol derivatives [11]. This is good because excess cholesterol in the body has been implicated as a contributory factor to non- communicablediseases such as gallstones, atherosclerosis and stroke [12]. Ukpa had a potential for being used in dietary formulation or supplementing low protein.

Therefore an attempt should be made to provide low cost complementaryfoods that are based on ukpa. Also, ukpa is very rich in fat content and thus can be used to produce vegetable oils. Ukpa contains appreciable quantities of carbohydrate $11.2 \mathrm{~g} / 100 \mathrm{~g}$ edible portion thus, Ukpa can make substantial contribution to energy intake of those who consume the seeds.Paw-paw is very rich in carbohydrate and it serves as snacks and usually taken at lunchtime. Carbohydrate is necessary in the diet since it has a protein sparing function [13; 14\&15]. 
Uziza, bitterleaf and garden egg were also high in protein and therefore could be added to our diet to upgrade the nutrients content. The consumption of ukazi which was also high in fibre $(4.9 \mathrm{~g} / 100 \mathrm{~g}$ edible portion) should be encouraged.

\section{Micronutrientand Anti-nutrient Composition of Selected Indigenous Foodcrops}

Inadequacy of vitamin A, iron and iodine are the major micronutrient problem in the world[16].The result revealed that addition of Telferiawith high zinc content in our daily diet will help to increase growth rate [17]. Utazi with high iron and calcium content and is added to the diets of lactating mothers and iron plays a vital role in blood formation [13]. Utazi could also be used as food supplements in our diet as itwas found to be high in calcium. It could thus play a useful role in bone formation.

Most of the food items that were rich in micronutrient contained anti-nutrients(phytate and tannins). Thus the portion made available for consumption was low. However, plant proteins were important source of incomplete protein in the diet of human beings. Thus, plantsproteins should not be used as the sole source of protein for children, pregnant and lactating mothers [18].

The result confirmed that our indigenous fruits, seed and vegetables were sources of important minerals and vitamins. This is in line with the findings of [19] that Nigeria leafy vegetables contributed a significant proportion of the zinc, iron, calcium and carotene to the traditional diet.

It was observed that the edible portion of iron found in ukazi was higher than in any other vegetables studied. Thus, increasing the usage of our indigenous vegetables especially ukazi in our diet will help in blood cell formation and reduce the incidence of anaemia in Nigerian children and pregnant women.Moreover, it did seem that a significant per cent of the daily iron requirement for the average Nigerian could be met through judicious selection and consumption of leafy green vegetables especially ukazi. Edible calcium content in bitterleaf was higher than in any other leafy vegetable studied. This indicated that addition of bitterleaf in our diet will help in bone formation. Also, the $0.31 \mathrm{mg}$ calcium per $100 \mathrm{~g}$ in ukazi was in line with the findings of Ibe [20]. In the view of these findings, our indigenous foodcrops are rich innutrients. They could contribute to the nutritional quality of meal and also make for variety in the choices of available foods. In addition, it will obviously lead to achieving household and consequently nationalfood security.

\section{Conclusion}

Indigenous fruits seeds and vegetableshave been shown to make substantial contribution in meeting the nutritional needs of the population in both urban and rural areas especially in times of seasonal scarcity of staple foods crops. This work has provided some additional information on the micronutrient contents of some underutilized indigenous fruits seeds and vegetables.

The analysed indigenousfruit, seed, and vegetables were rich in the following nutrients; zinc, iron calcium and vitamin A. Ukpa has the potential for improving local diets. The high protein content of uziza and bitterleaf could help in meeting individual protein requirements, if the intake is sufficiently high. The major constraint for the optimal use of ukpa was its long cooking time and high fuel consumption. Appropriate techniques for reducing fuel consumption rate and cooking time should be developed. Further detailed research on its nutritional contribution can be suggested. This will help to maximise the use of our rich indigenousfood crops which will lead to the improvement of the nutritional status of the Nigerians.

\section{Recommendations}

Based on findings the following recommendations are made.

I. There is need to enlighten the populace on the nutritional potential of these indigenous foodcrops.

II. The government should make policies that will promote the production of these indigenous foodcrops. This is necessary now that government is emphasizing on agricultural sector as a means of increasing food production, hence, ensuring food security. .

III. Ukpa seed should be used in dietary formulation or in supplementing low protein foods/complementary diets.

\section{References}

[1]. Kuhnlein, H.V. and Turner, N.J. (2009). Traditional Plant Foods of Canadian Indigenous Peoples . Vol.9. www.fao.org/wairdocs

[2]. FAO United Nation. (2014). Symposium on Sustainable Indegeneous African Diets For Food And Nutrition Security, November, 2014.

[3]. Vanham, D., and Bidoglio, G. (2013). “A review on the indicator water footprint for the EU28,” Ecol. Ind. $26,61-75$.

[4]. Global Nutrition Report, 2014

[5]. Von Grebmer, K., A. Saltzman, E. Birol, D. Wiesman, N. Prasai, S. Yin, Y. Yohannes, P. Menon, J. Thompson, and A. Sonntag. (2014). 2014 Global Hunger Index: The Challenge of Hidden Hunger Washington, DC: International Food Policy Research Institute; Dublin: Concern Worldwide; Bonn: Welthungerhilfe 
[6]. Ng, M. T. Fleming, M. Robinson, B. Thomson, N. Graetz, C. Margono, E. C. Mullany, et al. 2014 “Global, Regional, and National Prevalence of Overweight and Obesity in Children and Adults during 1980-2013: A Systematic Analysis for the Global Burden of Disease Study 2013." The Lancet 384 (9945) 766-781. http://dx.doi.org/10.1016/S0140-6736(14)60460-8

[7]. Ene-Obong, H. N., Elizaberth,c.O.,Anthonia, A.U., Nnaemeka,C.,Simeon,I.U., Alfred, O.(2012). The Igbo Traditional Food System Documented In Four States In Southern Nigeria.

[8]. AOAC, Official Method of Analysis, Association of Official and Analytical Chemist, (2012).

[9]. Latta, M. and Eskin, M. (1980). A Simple and Rapid Calorimetric Method for Phytate Determination; J. Agric. Food Chem. 28: 1313 .

[10]. Price , M. L. and Butler, L.G. (1997). Rapid Visual Estimation and Spectrophotometric determination of Tannin Content of Sorgum Grain: J. Agric. Food, Chem 25(6): 1268.

[11]. Tver, D.F. and Russell, P. (1989). The Nutritive and Health Encyclopedia: Second Edition, PP. 113-115.

[12]. Hale, W.G. And Margham, J.P., (1988).Dictionary Of Biology First Edition. Harpe Collins Publishers P. 126.

[13]. John, Y. (1977). Diet Of Man: Needs And Wants; Applied Science Publishers Ltd, London.

[14]. Garman,P.M. and Sherrington, K.B. (2013). An Introduction to Food Science, Nutrition and Microbiology. https://books.google.com.ng/books?isbn=1483136337

[15]. Nall, R. (2015) : Explain Why carbohydrates are said to Spare Proteins. www.Lingstrong.com

[16]. Garrow, J.S., James, W.P.T. And Ralpha (2000) Human Nutrition And Dietetics 10thEdition, Churchil Living Stone.

[17]. Maret , W and Sandstead, H.H (2006). Zinc requirement and the risks and benefits of Zinc supplementation. JTraceElemen.MedBiol 20:3-18.[PubMed abstract

[18]. Gates J.C. (1984). Basic Foods. Holt, Rinchart and Winston,Canada, Pp. 171, 186-192

[19]. Smith, I. F.(1982)Leafy Vegetables as A Source Of Minerals In Southern Nigerian Diets.Nutrition Report International. 26 (4), Pp 679-688.

[20]. IbeIjeoma (1994). The Consumption Pattern , Utilization And Chemical Evaluation Of Indigenous Food Crops ( Ukpa, Uke, Uha, Nturukpa, Ukazi). 